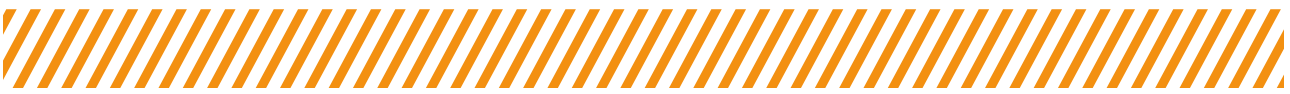

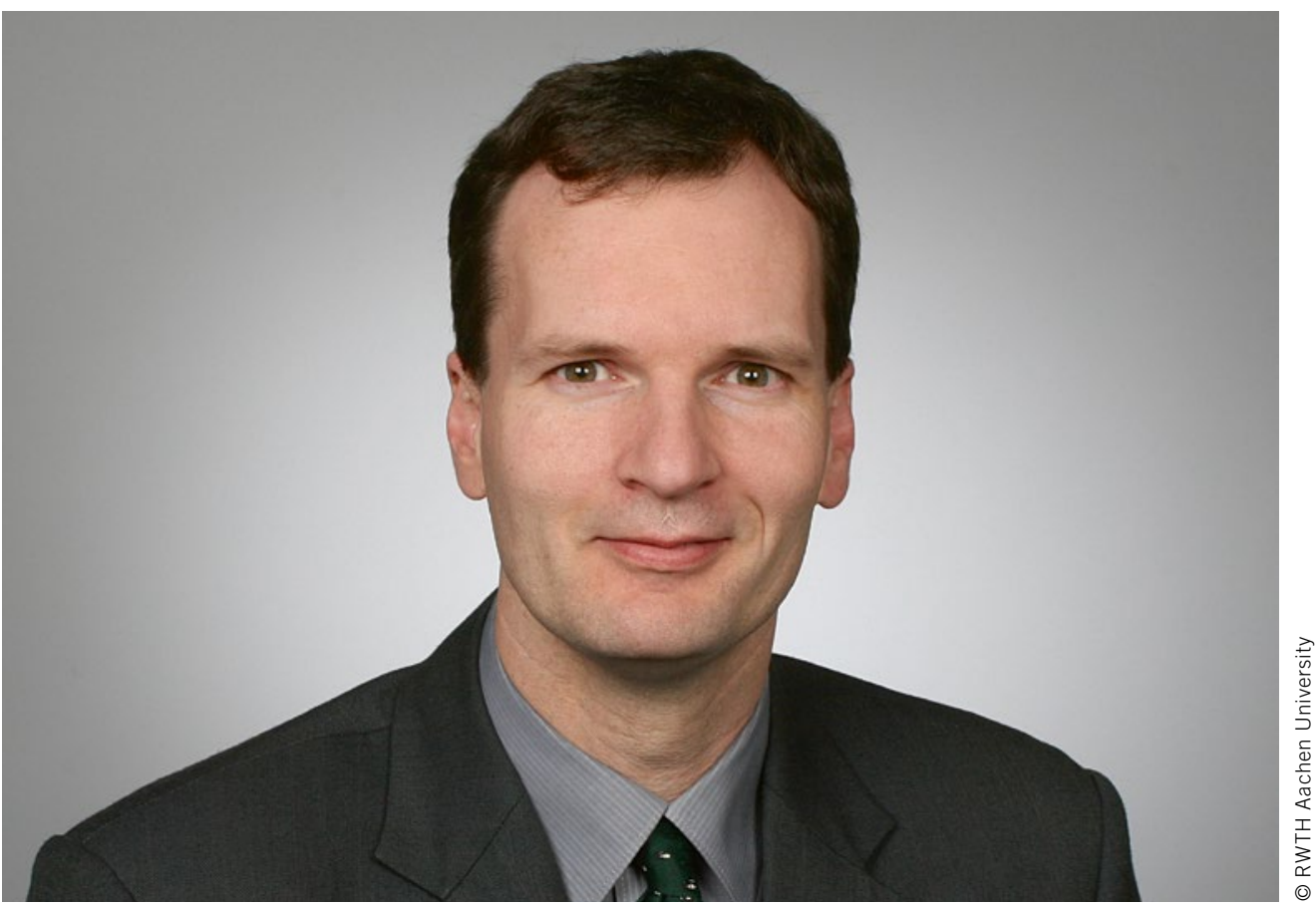

Dr. Dirk Uwe Sauer

Professor for Electrochemical

Energy Conversion and

Battery Technology,

RWTH Aachen University

\section{Don't Wait for the Next Battery-cell Generation}

Two core competences will be essential for success on the automobile market of the future: battery technology and autonomous driving technology. Those who fail to master both disciplines will have to accept a role as an intermediate supplier. Automakers in Germany are therefore urgently advised to work towards the establishment of at least one competitive production line in Germany or in Europe. In contrast, the answers to questions concerning how this is to be done may take on any degree of complexity. Who is going finance and operate the factories? Who is going to build the factories? And how long will it take to reach a satisfactory return on investment?

In order to avoid a misunderstanding: the task at hand is to build a facility for battery-cell production using the know-how of domestic companies. Production plants established by Asian manufacturers or on the model of the U.S.-based Gigafactory (Tesla and Panasonic) will make an appearance in Europe one way or another. All things considered, the companies that invest in battery-cell production plants on the basis of their own know-how will not be OEMs. It will take at least five, or more likely seven, years until the battery cells any given company decides to produce make it from the production plant to a vehicle on a production line. If the production plants are operated by European systems engineers, a somewhat smaller pilot line will have to be built and tested before the experience can be used as base for scaling upward to full capacity. Then it will take at least 1.5 years until production with sufficient quality and reproducibility is achieved. These battery cells can then move to the qualification stage at the OEMs and will certainly not make it to serial production any sooner than two years later. If an OEM were to go into battery-cell production, it would have to count on getting shut out of the know-how loop immediately by its previous suppliers, and perhaps even getting shut out of the supply loop. The material suppliers will also not be interested in alienating their existing customers in Asia so as to invest in their own battery-cell production capacities. There remain the Tier 1s, or startups with a major moneylender with a lot of patience. The factory to be built should have the size of the Gigafactory, and thereby have the capacity to supply batteries accounting for 1 to $2 \%$ of global passenger vehicle production.

If an entry is to succeed, then the company will have to be started now. Those who prefer to wait for the "next generation" are destined to fail. In the long term, the further development of battery-cell technology will also be evolutionary and largely based on previous production engineering and systems. Those who are already in the business will continue to enjoy advantages. The inclination to wait for a new generation as a sign of when to get involved is delusional. It's like what we heard seven years ago in Germany: "The Asians can only do consumer batteries. Given that the requirements for automobile batteries are something else altogether, they don't really have a significant technological head start”. 